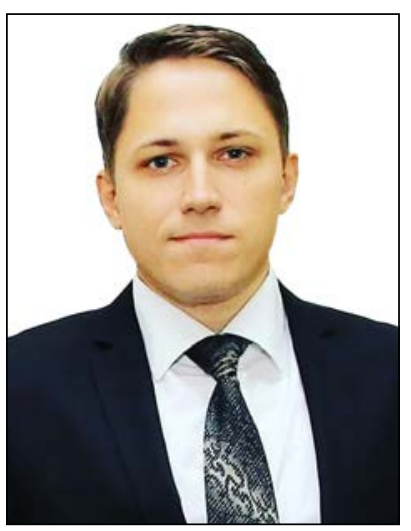

Shpak Maksym Volodymyrovych, PhD in Law, Assistant Professor of the Department of Civil Procedure, Yaroslav Mudryi National Law University, Ukraine, Kharkiv e-mail:maximshpak93@gmail.com ORCID 0000-0003-2119-3828

\title{
CERTAIN ASPECTS OF GIVING LEGAL AID IN THE COURTS OF UKRAINE IN CIVIL PROCESS IN MODERN CONDITIONS
}

Modern legal and judicial practice is constantly faced with problems of shortage of judges and as a result there is a big amount of unresolved cases in civil proceedings. This trend is observed from year to year. This problem is closely related to the fact that due to the insufficient number of judges in some courts of Ukraine, the process of providing legal aid by different groups of subjects is significantly complicated due to the actual impossibility of implementing proceedings in a particular court. Moreover, in Ukraine there are cases when there are no judges in the courts who have the power to administer justice. In this regard, in this research, the author is trying to examine the situation of legal aid cases in civil proceedings, taking into account statistics on the number of judges in Ukraine and the number of civil cases considered by courts in recent years.

It is seemed that providing a legal aid in civil proceedings depends not only on the professional skills of the representative. It depends on the legal environment where it is provided. This is due to the fact that, for example, due to the absence of judges in a particular court, a lawyer cannot provide other types of legal aid, except drawing up and filing a statement of claim. For example, this may be the case in a family case where persons have filed a lawsuit for divorce at the place of residence, but due to the absence of judges in court, the case cannot be considered. Because of this: 1) representatives (including lawyers) cannot provide the legal aid in the court proceedings; 2) the parties in such case will have to wait a long time, when a judge will be appointed to the case.

In recent years, legal aid in the civil process of Ukraine has become increasingly in demand. For the full implementation of legal aid in civil cases in Ukraine, it is necessary that persons who provide it, constantly further training, improve professional skills and abilities.

Keywords: civil proceedings; legal aid; lawyer; judge; prosecutor; expert; civil proceedings.

Шnак M. B., кандидат юридичних наук, асистент кафедри цивільного процесу, Національний юридичний університет імені Ярослава Мудрого, Україна, м. Харків.

e-mail: maximshpak93@gmail.com ; ORCID 0000-0003-2119-3828 
Окремі проблеми надання правової допомоги у судах України у цивільному процесі в сучасних умовах

Сьогодні залишається значною кількість нерозглянутих справ у порядку цивільного судочинства через нестачу суддівських кадрів в Україні. 3 огляду на недостатню кількість суддів в деяких судах України значно ускладнюється процес надання правової допомоги з боку різного кола суб'єктів через фактичну неможливість здійснення судочинства у конкретному суді. Непоодинокі випадки коли в судах узагалі немає суддів, які мали б повноваження на здійснення правосуддя.

У статті зроблена спроба вивчити стан справ щодо надання правової допомоги у порядку цивільного судочинства, враховуючи статистичні дані щодо кількості суддів в Україні та числа розглянутих цивільних справ судами протягом останніх років.

Надання правової допомоги у цивільному процесі багато в чому залежить не тільки від професійної майстерності представника, а й від юридичного середовища, де вона надається. Приміром, через брак суддів у певному суді адвокат не може надати інші види правової допомоги, крім складення та подання позовної заяви. Через це: 1) представники (в тому числі адвокати) не можуть надати правову допомогу у судовому процесі; 2) сторонам у такій справі доведеться чекати тривалий час, коли все ж таки буде призначений суддя.

Наголошено, що для повноцінної реалізації правової допомоги у цивільних справах в Україні важливо, щоб суб'єкти ї̈ надання постійно підвищували свою кваліфікащію, професійні навички та вміння.

Ключові слова: цивільний процес; правова допомога; адвокат; суддя; прокурор; експерт; цивільне судочинство.

Formulation of the problem. Modern legal and judicial practice is constantly faced with problems of shortage of judges and as a result there is a big amount of unresolved cases in civil proceedings. This trend is observed from year to year. This problem is closely related to the fact that due to the insufficient number of judges in some courts of Ukraine, the process of providing legal aid by different groups of subjects is significantly complicated due to the actual impossibility of implementing proceedings in a particular court. Moreover, in Ukraine there are cases when there are no judges in the courts who have the power to administer justice. In this regard, in this research, the author is trying to examine the situation of legal aid cases in civil proceedings, taking into account statistics on the number of judges in Ukraine and the number of civil cases considered by courts in recent years.

The relevance of the study is explained by the really problematic particularities of the issue. Therefore, its study requires detailed attention.

Analysis of recent research and publications. The activity of judges and the functioning of courts in the context of the civil process of Ukraine have been the subject of scientific research of native scholars-proceduralists, among which it is necessary to highlight the thorough works of K. V. Gusarov [1; 2; 3]. This scholar paid a lot of attention to the study of judicial specialization, administration of justice and the exercise of powers by the courts.

The purpose of the article is to study the current problems of providing legal aid in civil proceedings, taking into account current statistics on the number of civil cases and the total number of judges in Ukraine. 
Presenting of the main material. It should be noted that as of 01.01.2019, the actual number of judges in Ukraine was 5511 [4]. As of April 10, 2020, out of 7,295 positions, only 5,166 were filled, of which only 4,729 judges had the power to administer justice [5]. As of October 16, 2020, the number of judges was 5,363 out of the identified 7,295, of which 4,809 had the right to administer justice [6].

Taking into account the above statistical information on the number of judges in Ukraine in recent years, it is also necessary to pay attention to the statistics on the consideration of cases by courts in civil proceedings. It should be emphasized that according to the Analysis of situation of administration of justice in civil cases in 2018 in trial courts were considered more than 1.2 million claims, applications, complaints, petitions of court cases by civil litigation. At the end of this reporting period, 291.1 thousand cases and materials remained unresolved in civil proceedings. In the proceedings of the appellate courts during 2018 there were 108.7 thousand appeal complaints and materials, but the percentage of unresolved reached $31.1 \%$ [7, p. 3, 4, 7, 8]. Given the above-mentioned judicial statistics of consideration in 2018 by trial and appellate courts of cases in civil proceedings, it should be emphasized that in general such data indicate the necessity to increase the number of judges. As due to insufficient number of judges, almost every fourth case in the court of first instance in 2018 remained unresolved at the end of the year.

It is possible to assume that in a number of such cases there was the providing legal aid in the form of procedural representation. However, due to unresolved cases, we assume that the representatives could not to use all their professional knowledge, skills and abilities to provide legal aid. This is an important and fundamental point, because in every court case the destiny of people is decided - people who go to court to protect their rights. In this regard, in our opinion, there is a great need for a new professional selection of new judges for the relevant positions in the trial and appellate courts. And important and key in this matter should be not only the qualifications, but also a sufficient number of judges who will administer justice in civil cases.

According to the Analytical Review of the Status of Civil Proceedings in 2019, trial courts considered 1 million 249 thousand claims, applications, complaints, petitions of court cases in civil proceedings. The number of cases and materials considered in these courts in civil proceedings was 955.1 thousand. In the appellate courts during 2019 there were about 105 thousand appeal complaints and materials, only 84.4 thousand were considered [8, p. 3, 9, 10].

Taking into account the above statistics for 2019 on the consideration of cases by trial and appellate courts in civil proceedings, the following should be emphasized. As for the trial courts, the number of unresolved cases remained at the end of the reporting year, according to our estimations, almost similar to 2018. As for the appellate courts, the number of resolved appeal complaints and materials in 2019 increased comparing to 2018. However, even taking into account the positive trend of increasing the number of resolved cases in the appellate court, the question of the number of unresolved cases remains important. The reason of 
absence in this research the statistical information for 2020 on the status of trial and appellate courts of Ukraine in civil proceedings for the mentioned year, on the official website there are no relevant statistics data for the full 2020 at the time of writing this work.

Taking into account the above considerations and statistics on the number of judges in Ukraine, as well as the statistics of civil proceedings in courts of trial and appellate courts, it is believed that the providing a legal aid in civil proceedings depends not only on the professional skills of the representative. It depends on the legal environment where it is provided. This is due to the fact that, for example, due to the absence of judges in a particular court, a lawyer cannot provide other types of legal aid, except drawing up and filing a statement of claim. For example, this may be the case in a family case where persons have filed a lawsuit for divorce at the place of residence, but due to the absence of judges in court, the case cannot be considered. Because of this: 1) representatives (including lawyers) cannot provide the legal aid in the court proceedings; 2) the parties in such case will have to wait a long time, when a judge will be appointed to the case.

The issue of providing legal aid in civil proceedings is closely related to the subjective composition of such legal relations. One of the types of legal aid in the civil process of Ukraine is a professional legal aid provided by lawyers. It should be noted that the process of obtaining the status of a lawyer in Ukraine involves a multi-stage procedure. In this regard, it is worth noting the interesting court practice for February 2021, which raised the issue of aspects of gaining the right to practice the advocacy law by current judges of Ukraine. This issue was covered in the Resolution of the Grand Chamber of the Supreme Court of February 10, 2021.

It should be noted that paragraph 65 of this decision states that the training of current judge for six months under the guidance of a lawyer in order to obtain a lawyer's certificate goes beyond the permissible areas of relations between judges and lawyers [9].

Analyzing such provisions of the practice of the Grand Chamber of the Supreme Court in this order, it is necessary to specify the following value for civil proceedings.

- First, the current judge cannot be under two oaths (judicial and lawyer) at the same time.

- Second, the professions of lawyer and judge must be independent of each other.

In general, it should be noted that the question of the connection between judicial practice and the providing a legal aid in civil cases has always been of interest to procedural scholars. This is confirmed by many scientific works of native and foreign scientists.

A significant contribution to the study of civil proceedings was made by V. V. Komarov, who repeatedly presented his innovative and progressive ideas in the pages of legal literature [10]. The scientific research of this scientist is fundamental and is clearly important for studying of various problems of civil justice. 
Conclusions. In recent years, legal aid in the civil process of Ukraine has become increasingly in demand. For the full implementation of legal aid in civil cases in Ukraine, it is necessary that persons who provide it, constantly further training, improve professional skills and abilities.

\section{Список літератури}

1. Гусаров К. В. Судебная власть и правосудие по гражданским делам в Украине. Становлення правової системи демократичної України та юридична наука : короткі тези доп. та наук. повідом. наук. конф. молодих учених та аспірантів / за заг. ред. проф. М. І. Панова. Харків : Нац. юрид. акад. України, 1998. С. 43-45. URL: http://dspace.nlu.edu.ua/bitstream/123456789/13320/1/ Gusarov_43-45.pdf (дата звернення: 08.03.2021).

2. Гусаров К. В. Повноваження суду касаційної інстанції у цивільному судочинстві. Право $i$ безпека. 2006. № 5. C. 54-63. URL: http://irbis-nbuv.gov.ua/cgi-bin/irbis_nbuv/cgiirbis_64.exe ? I21DBN=LINK\&P21DBN=UJRN\&Z21ID $=\& S 21 \mathrm{REF}=10 \& \mathrm{~S} 21 \mathrm{CNR}=20 \& \overline{\mathrm{S}} 21 \mathrm{STN}=1 \& \mathrm{~S} 21 \mathrm{FMT}$ $=\mathrm{ASP} \_$meta\&C21COM=S\&2_S21P03=FILA=\&2_S21STR=Pib_2006_5_5_17 (дата звернення: 08.03.2021).

3. Гусаров К. В. Засади суддівської спеціалізації: чи доцільні зміни? Актуальні проблеми судового права : матеріали міжнар. наук.-прак. конф., присвяч. пам'яті проф. І. С. Марочкіна (Харків, 30 жовт. 2015 р.) Харків. 2015. С. 26-28. URL: http://dspace.nlu.edu.ua/ bitstream/123456789/9609/1/Gusarov_26_28.pdf (дата звернення: 09.03.2021).

4. В Україні серед суддів більше жінок, ніж чоловіків. URL: https://www.unn.com.ua/ uk/news/1856702-v-ukrayini-sered-suddiv-bilshe-zhinok-nizh-cholovikiv-2 (дата звернення: 09.03.2021).

5. Матола В. 23 \% судів в Україні не заповнені навіть на половину. URL: https://b.ua/ pravo/2020/05/22/458140_23_sudov_ukraine_zapolneni_dazhe.html (дата звернення: 09.03.2021).

6. Кандидати на посаду судді: призначити неможливо чекати. URL: https://kr.su. court.gov.ua/archive/1016683/\#: :text=\%D0\%A1\%D1\%82\%D0\%B0\%D0\%BD\%D0\%BE\%D $0 \% \mathrm{BC} \% 20 \% \mathrm{D} 0 \% \mathrm{BD} \% \mathrm{D} 0 \% \mathrm{~B} 0 \% 2016 \% 20 \% \mathrm{D} 0 \% \mathrm{~B} 6 \% \mathrm{D} 0 \% \mathrm{BE} \% \mathrm{D} 0 \% \mathrm{~B} 2 \% \mathrm{D} 1 \% 82 \% \mathrm{D} 0 \% \mathrm{BD} \% \mathrm{D}$ $1 \% 8 \mathrm{~F} \% 202020$ \% D0\%B2\%D0\%B0\%D0\%BA\%D0\%B0\%D0\%BD\%D1\%82\%D0\%BD\%D0\%B $8 \%$ D1\%85\%20\%D0\%BF\%D0\%BE\%D1\%81\%D0\%B0\%D0\%B4\%20\%D1\%81\%D1\%83\%D0\%B4 $\%$ D0\%B4\%D1\%96\%D0\%B2\%20\%D1\%81\%D1\%82\%D0\%B0\%D0\%BD\%D0\%BE\%D0\%B2\%D0\%B8\%D1\%82\%D1\%8C\%201932 (дата звернення: 09.03.2021).

7. Аналіз стану здійснення правосуддя при розгляді цивільних справ у 2018 p. URL: https:// supreme.court.gov.ua/userfiles/media/Analiz_KCS_2018_1.pdf (дата звернення: 10.03.2021).

8. Аналітичний огляд стану здійснення цивільного судочинства у 2019 p. URL: https:// supreme.court.gov.ua/userfiles/media/Analiz_Civil_sudu_2019.pdf (дата звернення: 11.03.2021).

9. Постанова Великої Палати Верховного Суду від 10 лютого 2021 р. Справа № 822/1309/17. URL: https://reyestr.court.gov.ua/Review/95439673?fbclid=IwAR3TYIts3FJlwoJEdd3XID0CZ0Rrf Yj1zZVrFqv-SydVl2JljubFdzuHYLY (дата звернення: 14.03.2021).

10. Комаров В. В. Цивільне процесуальне законодавство у динаміці розвитку та практиці Верховного Суду України. Харків : Право, 2012. 624 с.

\section{References}

1. Husarov, K.V. (1998). Sudebnaia vlast y pravosudye po hrazhdanskym delam v Ukrayne. Stanovlennia pravovoi systemy demokratychnoi Ukrainy ta yurydychna nauka: korotki tezy dop. ta nauk. povidom. nauk. konf. molodykh uchenykh ta aspirantiv. M. I. Panov (Ed.). Kharkiv: Nats. yuryd. akad. Ukrainy, 43-45. URL: http://dspace.nlu.edu.ua/bitstream/123456789/13320/1/Gusarov_43-45.pdf [in Russian].

2. Husarov, K.V. (2006). Povnovazhennia sudu kasatsiinoi instantsii u tsyvilnomu sudochynstvi. Pravo i bezpeka, 5, 54-63. URL: http://irbis-nbuv.gov.ua/cgi-bin/irbis_nbuv/cgiirbis_64.exe?I21D 
$\mathrm{BN}=\mathrm{LINK} \& \mathrm{P} 21 \mathrm{DBN}=\mathrm{UJRN} \& \mathrm{Z} 21 \mathrm{ID}=\& \mathrm{~S} 21 \mathrm{REF}=10 \& \mathrm{~S} 21 \mathrm{CNR}=20 \& \mathrm{~S} 21 \mathrm{STN}=1 \& \mathrm{~S} 21 \mathrm{FMT}=\mathrm{ASP}$ meta\&C21COM=S\&2_S21P03=FILA $=\& 2 \_S 21 S T R=$ Pib_2006_5_5_17 [in Ukrainian].

3. Husarov, K.V. (2015). Zasady suddivskoi spetsializatsii: chy dotsilni zminy? Aktualni problemy sudovoho prava: materialy mizhnar. nauk.-prak. konf., prysviach. pamiati prof. I. Ye. Marochkina (Kharkiv, 30 zhovt. 2015 r.) Kharkiv, 26-28. URL: http://dspace.nlu.edu.ua/bitstream/123456789/9609/1/ Gusarov_26_28.pdf [in Ukrainian].

4. $\overline{\mathrm{V}}$ Ukraini sered suddiv bilshe zhinok, nizh cholovikiv. URL: https://www.unn.com.ua/uk/ news/1856702-v-ukrayini-sered-suddiv-bilshe-zhinok-nizh-cholovikiv-2 [in Ukrainian].

5. Matola, V. $23 \%$ sudiv v Ukraini ne zapovneni navit na polovynu. URL: https://lb.ua/ pravo/2020/05/22/458140_23_sudov_ukraine_zapolneni_dazhe.html [in Ukrainian].

6. Kandydaty na posadu suddi: pryznachyty nemozhlyvo chekaty. URL: https://kr.su. court.gov.ua/archive/1016683/\#: :text=\%D0\%A1\%D1\%82\%D0\%B0\%D0\%BD\%D0\%BE\%D $0 \% \mathrm{BC} \% 20 \% \mathrm{D} 0 \% \mathrm{BD} \% \mathrm{D} 0 \% \mathrm{~B} 0 \% 2016 \% 20 \% \mathrm{D} 0 \% \mathrm{~B} 6 \% \mathrm{D} 0 \% \mathrm{BE} \% \mathrm{D} 0 \% \mathrm{~B} 2 \% \mathrm{D} 1 \% 82 \% \mathrm{D} 0 \% \mathrm{BD} \% \mathrm{D}$ $1 \% 8 \mathrm{~F} \% 202020, \% \mathrm{D} 0 \% \mathrm{~B} 2 \% \mathrm{D} 0 \% \mathrm{~B} 0 \% \mathrm{D} 0 \% \mathrm{BA} \% \mathrm{D} 0 \% \mathrm{~B} 0 \% \mathrm{D} 0 \% \mathrm{BD} \% \mathrm{D} 1 \% 82 \% \mathrm{D} 0 \% \mathrm{BD} \% \mathrm{D} 0 \% \mathrm{~B}$ 8\%D1\%85\%20\%D0\%BF\%D0\%BE\%D1\%81\%D0\%B0\%D0\%B4\%20\%D1\%81\%D1\%83\%D0\%B4 \%D0\%B4\%D1\%96\%D0\%B2\%20\%D1\%81\%D1\%82\%D0\%B0\%D0\%BD\%D0\%BE\%D0\%B2\%D0\%B8\%D1\%82\%D1\%8C\%201932 [in Ukrainian].

7. Analiz stanu zdiisnennia pravosuddia pry rozghliadi tsyvilnykh sprav u 2018 r. URL: https:// supreme.court.gov.ua/userfiles/media/Analiz_KCS_2018_1.pdf [in Ukrainian].

8. Analitychnyi ohliad stanu zdiisnennia tsyvilnoho sudochynstva u 2019 r. URL: https:// supreme.court.gov.ua/userfiles/media/Analiz_Civil_sudu_2019.pdf [in Ukrainian].

9. Postanova Velykoi Palaty Verkhovnoho Sudu vid 10 liutoho 2021 r. Sprava № 822/1309/17. URL: https://reyestr.court.gov.ua/Review/95439673?fbclid=IwAR3TYIts3FJlwoJEdd3XID0CZ0Rrf Yj1zZVrFqv-SydVl2JljubFdzuHYLY [in Ukrainian].

10. Komarov, V.V. (2012). Tsyvilne protsesualne zakonodavstvo u dynamitsi rozvytku ta praktytsi Verkhovnoho Sudu Ukrainy. Kharkiv: Pravo [in Ukrainian].

Шиак M. В., кандидат юридических наук, ассистент кафедры гражданского процесса, Национальный юридический университет имени Ярослава Мудрого, Украина, г. Харьков.

e-mail: maximshpak93@gmail.com ; ORCID 0000-0003-2119-3828

\section{Отдельные проблемы оказания правовой помощи в судах Украины в гражданском про- цессе в современных условиях}

Современная юридическая и судебная практика постоянно соприкасается с проблемами нехватки судейских кадров. Такая тенденция наблюдается из года в год.

Эта проблема тесно связана с тем, ито из-за недостатка судей в некоторых судах Украины значительно усложняется прочесс оказания помощи со стороны разного круга субъектов в связи с фактической невозможностью осуществления судопроизводства в конкретном суде.

Автор делает попытку исследовать состояние дел относительно предоставления правовой помощи в порядке гражданского судопроизводства, учитывая статистические данные по количеству судей в Украине и количества рассматриваемых гражданских дел судами в последние годь.

Предоставление правовой помощи в гражданском прочессе во многом зависит не только от профессионального мастерства представителя. Это существенно зависит и от юридической среды, где она предоставляется. Это объясняется тем, например, что из-за отсутствия судей в определенном суде адвокат не может предоставить другие виды правовой помощи, кроме составления и подачи искового заявления. К примеру, ситуация в семейном деле, когда лица подали в суд иск о расторжении брака по месту жительства, но из-за отсутствия судей в суде дело не может быть рассмотрено. Поэтому: 1) представители (в том числе адвокаты) не могут оказать правовую помощь в судебном процессе; 2) сторонам в таком деле придется ждать немалое время, когда все же будет назначен судья на дело. 
Для полноценной правовой помощи по гражданским делам в Украине важно, чтобы субъекты ее предоставления постоянно повышали свою квалификащию, профессиональные навыки и умения.

Ключевые слова: гражданский процесс; правовая помощь; адвокат; судья; прокурор; эксперт; гражданское судопроизводство.

Рекомендоване цитування: Shpak M. V. Certain aspects of giving legal aid in the courts of Ukraine in civil process in modern conditions. Проблеми законності. 2021. Вип. 153. С. 49-55. doi: https://doi.org/10.21564/2414-990X.153.229448.

Suggested Citation: Shpak, M.V. (2021). Certain aspects of giving legal aid in the courts of Ukraine in civil process in modern conditions. Problemy zakonnosti - Problems of Legality, issue 153, 49-55. doi: https://doi.org/10.21564/2414-990X.153.229448.

Надійшла до редколегії 29.04.2021 p. 